\title{
Becoming a CPA-How to Attract University Students to the Accounting Profession Using Theory of Planned Behavior?
}

\author{
Hasan Yousef El-Mousawi ${ }^{1}$, Abdulrazzak Charbaji ${ }^{2}$ \\ ${ }^{1}$ Department of Accounting, Faculty of Economics and Business Administration, Lebanese University, Beirut, \\ Lebanon \\ ${ }^{2}$ Lebanese University, Beirut, Lebanon \\ Email: h_mousawi@hotmail.com, info@charbaji.com
}

Received 30 February 2016; accepted 19 April 2016; published 22 April 2016

Copyright (C) 2016 by authors and Scientific Research Publishing Inc.

This work is licensed under the Creative Commons Attribution International License (CC BY). http://creativecommons.org/licenses/by/4.0/

(c) O) Open Access

\begin{abstract}
The purpose of this study is to determine the relative importance of factors that attract university students to the accounting profession in Lebanon using Theory of Planned Behavior. The significance of this study is based on the previous research which has shown that "intrinsic factors" (attitude toward the behavior) and "parental influence" (subjective norms) are significant predictors of career choice of accounting students. Using a very large judgmental sample from business students focusing on accounting, the researchers in this study constructed a reliable and valid instrument having one item measuring intention to pursue accounting career in Lebanon, four items measuring self efficacy, another four items measuring social influence (subjective norms) and five items measuring attitude and behavioral beliefs. The multiple regression analysis retained "Subjective Norms" in the model and removed "Beliefs and Attitude towards Accountant and CPA", "Self Efficacy", and "Perceived Behavioral Control". The current study showed that path analysis was not an acceptable fit of data. All predictors (paths) except the direct effect between "Subjective Norms" and "intention to pursue accounting career in Lebanon" should be deleted from the model. Findings of this study support that Hypothesis 1-Subjective Norms (perceived social pressure to become or not become CPA) will be a significant positive predictor of intention to Pursue a CPA Career. Furthermore, the current study provided implications for policy making and for further research.
\end{abstract}

\section{Keywords}

CPA Career, Theory of Planned Behavior, Social Influence, Accounting Students 


\section{General Background}

Studies have shown that over the last decade there has been a decline in the number of students studying accounting in several countries as reported by Albrecht, W.S. and Sack, R.J. [1] in the United States of America, Jackling, B. [2] in Australia, Marshall, R. [3] in United Kingdom; Wells, P. and Fieger, P. [4] in New Zealand and Sugahara, Hiramatsu, \& Boland [5] in Japan. According to Solikhah, B. [6], "The phenomenon got worse because since 1997, the growth of CPA tends to stagnate". Surveying graduate accounting students in Iran showed that students "believe that the shortage of appropriate text books about management accounting, unawareness of management accounting certificates, the shortage of seminars and workshops about management accounting, the existed limitations and barriers to research in the field of management accounting, firms' disinterest in implementing management accounting new techniques, engaging universities in merely theoretical matters, the absence of sufficient courses about management accounting in universities, journals' ignorance of management accounting, the absence of sufficient curriculum in universities about management accounting lead to a decrease in students' interest in management accounting” [7]. Inspecting accounting students in Jordanian universities showed that "Job opportunities and income were the most important factors that discouraged students to be interested in the management accounting profession” [8]. Investigating the perception of accounting professionals with respect to using International Financial Reporting Standards (IFRS) in Bahrain showed that "Nationalism may well continue to be a major impediment to global adoption of IFRS" [9]. Needless to say, Saleh, H.A. [10] a professor in the Lebanese university calls universities to adopt required training programs, such as "internship" to formulate governmental policies for bridging the gap between students' perception and choice of their profession. To guard against the decline in interest in accounting profession and in the intention to become a CPA holder in Lebanon, the Research Problem in the current research is to determine the relative importance of factors that attract university students to the accounting profession in Lebanon by the use of Theory of Planned Behavior. The Theory of Planned Behavior (TPB) is one of the most widely used frameworks for understanding and predicting behavior. It was developed as an extension to the Theory of Reasoned Action (TRA) which proposed that intention is the key determinant of behavior. Here, intention was defined as the motivation required to perform a particular behavior (such as CPA career). The Theory of Planned Behavior (TPB) posited that intention can be used as a proximal measure of behavior and as shown in Figure 1 below conceived intention as being determined by two key factors: attitudes and subjective norms [11]. Attitudes are general positive or negative evaluations of behavior. An attitude is assumed to result from two components: 1) behavioral beliefs about consequences of the behavior, and 2) the outcome expectancies of the behavior which are corresponding positive or negative value judgments about the behavior. Subjective norms are the global perceptions of social pressure, they indicate a person's own estimate of the perceived social pressure to perform or not perform the target behavior. Subjective norms are assumed to be incumbent upon one's normative beliefs, which are beliefs about how other people who are in some way important to the person (such as a parent, friend, older sibling or teacher) would like one to behave [11]. Saleh, H.A. [10] believes that "Orienting students, via family members and community activities, in addition to the university's role, lead to build positive social norms". Ajzen, I. [11] notes that "The best measure of Subjective Norms 'is usually obtained by asking respondents to rate the extent to which important others would approve or disapprove of their performing a given behavior'”. Further he notes that "Control beliefs may be based in part on past experience with the behavior, but they will usually also

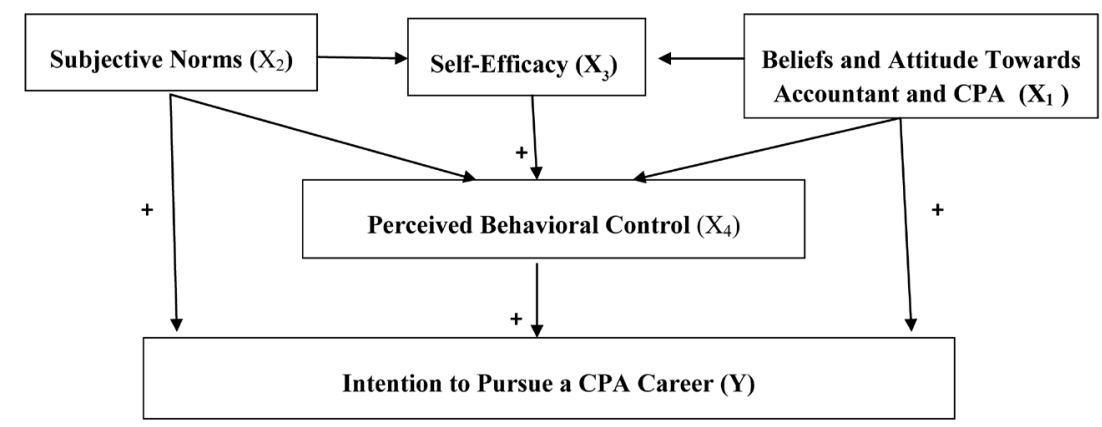

Figure 1. Modified model of the theory of planned behavior (TPB). Source: Theory of Planned Behavior (Ajzen, 1988). 
be influenced by second-hand information about the behavior, by the experiences of acquaintances and friends, and by other factors that increase or reduce the perceived difficulty of performing the behavior in question” [11]. The need for the current study and its importance are based on the previous research. [6] who was interested in attracting university students to the accounting profession believes that "Future research should develop the Planned Behavior Theory (PBT)". Buchan, H. [12] believes that "Future research should explore the factors in the public accounting domain that most strongly influence attitude formation. This study suggests that the theory of reasoned action offers a useful framework for exploring these issues”.

\section{Development of Research Hypotheses}

The hypotheses in the current study were formulated based on previous research. Prior research has shown that “'intrinsic factors' (attitude toward the behavior) and 'parental influence' (subjective norms), make significant and independent contributions to predicting the career choice of accounting students" [13]. Solikhah, B. [6] reported that "Attitude towards CPA and CPAs Law, subjective norms and perceived behavioral control influence the intention to pursue CPA career". Mbawuni, J. and Nimako, S.G. [14] believe that "Many people perceive accountants as unethical people who often manipulate figures in financial reports, often hide vita information in financial reports, often do not report the true state of affairs and often too rigid, legalistic”. The findings of [14] study show that "Five factors are key determinants of accounting students' intentions to pursue accounting careers. Among the significant predictors, feelings about accounting profession made the greatest influence on career intentions, followed by accountants' reputation, job requirements, job outcomes and self-efficacy" [14]. Djatej, A. Chen, Y. Eriksen, S. and Zhou, D. [15] note that "Applying the TRA model, an individual's intention to pursue an accounting major/career is determined by two main components: personal interest (attitude toward accounting) and social influence (perceived subjective norm). Personal interest is formed by one's perception about the accounting profession and one's accounting-related self-efficacy”. Nahariah, J., Norhazlin, I. and Salmi, M.Z. [16] found that their study "Contradict to those of [17] who demonstrate that gender and academic year have a significant interaction effect on student occupational aspirations and career-style preferences”. Ajzen, I. [11] believes that "Perception of behavioral control, attitude toward the behavior, and subjective norm each reveals a different aspect of the behavior, and each can serve as a point of attack in attempts to change it". Figure 1 shows that the following set of hypotheses were addressed in the current study:

Hypothesis 1-Subjective Norms (perceived social pressure to become or not become CPA) will be a significant positive predictor of intention to Pursue a CPA Career.

Hypothesis 2-Evaluation of CPA and beliefs about consequences (Attitude) will be a significant positive predictor of intention to pursue a CPA Career.

Hypothesis 3-Perceived Behavioral Control will be a significant positive predictor of intention to Pursue a CPA Career.

Hypothesis 4-Self-Efficacy will be a significant positive predictor of intention to pursue a CPA career.

\section{Review of Literature}

The history of the accounting profession in developed countries has been related to the history of capitalism. According to [18] "In 1904 eight people formed the London Association of Accountants. Their aim was to provide more open access to the accountancy profession than the two existing accountancy organisations. ACCA went through a number of mergers and amalgamations over the years. In 1984 we became the Chartered Association of Certified Accountants to reflect the fact that we had been granted a Royal Charter of Incorporation. In 1996 we began to use our current name, the Association of Chartered Certified Accountants (ACCA)". The story in developing countries such as Lebanon was different. The state played a vital role in development policies for long time and was forced to launch economic reforms as recommended by the World Bank. As a result, the big international firms soon arrived to the Lebanese shores. In 1997, the economist [19] reported that "On the one hand, the accountants seem hell-bent on becoming bigger than ever before: the Big Eight has already become the Big Six (and may soon become the Big Five)". According to the "Big 4 Accounting Firms" [20]:

"The Big 4 used to be known as Big 8 made up of (1) Arthur Andersen, (2) Arthur Young \& Co., (3) Coopers \& Lybrand, (4) Ernst \& Whinney, (5) Deloitte, Haskins \& Sells, (6) KPMG, (7) Touche Ross, and

(8) Price Waterhouse. It was after a series of mergers and dissolutions that brought about the elite four. In 
1989, two huge mergers reduced the Big 8 into the Big 6. Ernst \& Whinney merged with Arthur Young to form Ernst \& Young; and Deloitte, Haskins \& Sells with Touche Ross to form Deloitte Touche. Then in 1998, Price Waterhouse merged with Coopers \& Lybrand to form PricewaterhouseCoopers, famously known as PwC. It further reduced the group into the Big 5. In 2002, the five was cut by one due to the fall of Arthur Andersen after its involvement in the world-shocking Enron scandal. From then on, the four largest existing accounting firms have been known as the Big 4”.

Today, ACCA is a legal entity with 178,000 members and 455,000 students in 181 countries. It has a network of 92 offices and centers across the world [18]. Furthermore, Longuenesse, E. [21] notes that:

"In Lebanon, an accounting profession was recently institutionalised, through the creation of a professional corporatist association, the LACPA (Lebanese Association of Certified Public Accountants), or Ordre des Experts Comptables Libanais, OECL, in French. This unification has not yet allowed the profession to overcome the divisions and conflicts, which arouse from the conditions of its institutionalisation. Many professionals have worked in the Gulf countries, and a new generation of highly qualified accountants, open to international standards and codes, is by now arriving on the market”.

According to Longuenesse, E. [21] "The intervention of the state in accountancy regulation was minimum and late: surprisingly, it was during the civil war, in 1983, that an accounting system (plan compatible) was published, and a high council for accountancy created in 1984. As soon as 1996, the IAS were introduced and made compulsory for banks first, then progressively, for firms of different size”. Based on review of literature it is found that students decide on choosing CPA career when they are in high school or they become university newcomers. Mbekomize, C.J. and Kiiru, J.O.W. [22] discovered that undergraduate's exposure to accounting negatively impacted student's attitudes towards accounting. Furthermore, Mbekomize, C.J. and Kiiru, J.O.W. [22] report “that although high school students perceive accountants as 'professional' and 'intelligent', they are generally ignorant of what accountants do, have misinformation about the profession and associate accountants with 'maths' and "numbers'”. Lillian B Wally, D. [23] notes that the reasons of why taking accounting as a major "include availability of advancement opportunities, personal interest in the subject, availability of employment after graduation, prestige of the profession and high earning compared with other professions". Based on the experience of the current researchers in Lebanon, we may say that Lebanese students perceive accountants' work as tedious, boring and is based on number crunching. Most of university students may think that other professions such as medical doctors or engineering are more prestigious and enjoyable because you work with people and not alone. Yaacoub, N and Badre, L. [24] found that during the academic year 2009-2010, "It seems that the majority of students enrolled in the Lebanese University have chosen humanities and social sciences while students of other private universities preferred business oriented majors”. Moreover, Maheran, Z., Wan, N.A.W.F. and Siti, J.N.H. [25] believes that "Colleges and universities are the backbone of an appropriate professional education. The quality of their educational programs will drive the quality of professionals entering the market as accountants in business (preparers) or auditors in the future”.

\section{Procedures and Methods}

\subsection{Population and Sample Selection}

Since the researchers in this study did not have the right of entry to the names of accounting students in Lebanon and were unable to randomly select a representative sample of these students, therefore, the researchers in the current study decided to use a very large judgmental sample from business students focusing on accounting. The findings of this study are based on valid responses from 330 accounting students. Figure 2 shows that 35\% of the selected samples are female students. The regression analysis in Table 7 shows that gender is not a significant explanatory variable.

\subsection{Instrumentation}

Based on review of literature and informal discussion with university colleagues in management and accounting in addition to the researchers' personal experience; the researchers in this study constructed an instrument having one item measuring intention to pursue accounting career in Lebanon, four items measuring self efficacy 


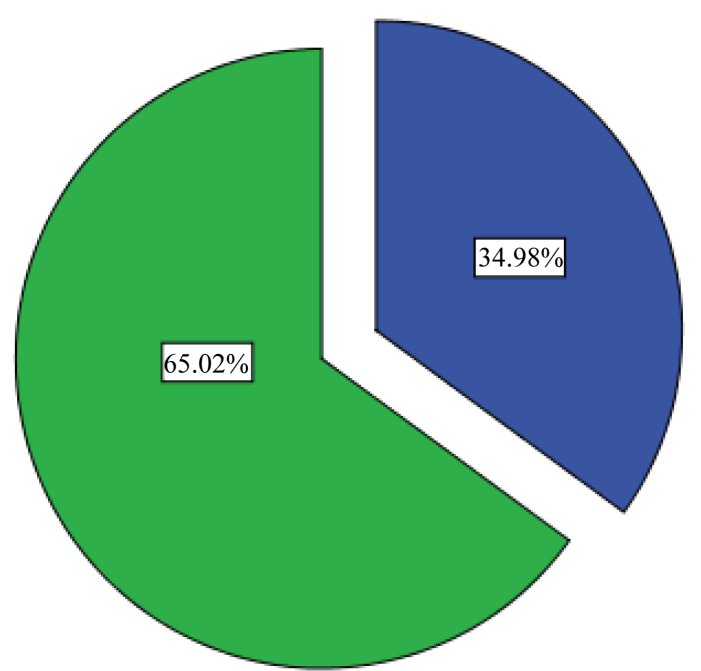

Figure 2. The gender distribution of the selected sample of accounting students.

and another four items measuring social influence (subjective norms) that were taken from the valid questionnaire constructed by [15] using 5 point Likert-type scale ranging from “ 1 ” SD to " 5 " SA. The other five items measuring attitude and behavioral beliefs were derived from the questionnaire constructed by [26] using 5 point Likert-type scale ranging from " 1 " SD to " 5 " SA. Findings of the current study shows that all subscales were reliable having Cronbach’s (alpha) ranging from 0.828 to 0.907 as shown in Table 1.

\subsection{Factor Analysis and Construct Validity}

Factor analysis was performed out as a data reduction technique. Two statistical tests were conducted in order to determine the suitability of factor analysis as shown in Tables 2-4. The KMO measure of sampling adequacy score of 0.674 was well above the recommended level of 0.5 and the Bartless test of sphericity was significant (Chi Square $=4834.326, \mathrm{P}=0.000$ ), indicating that there are adequate inter-correlations between the items which allow the use of factor analysis. Oblique factoring was used as a rotation method. Five factors were extracted using Eigenvalue greater than one criterion. The five factor solution accounted for 79.419 per cent of the total variance. The five factors were easy to label (see Table 4). The first factor was labeled "Beliefs and Attitude Towards Accountant and CPA (X1)” accounts for 29.891 percent of total variance and is defined by five items with factor loadings greater than 0.70. Table 1 shows that Cronbach's (alpha) for this factor is 0.907 . The second factor accounts for 17.632 percent of total variance and is defined by its four items with factor loadings greater than 0.70 and was labeled “Self Efficacy”. Table 1 above shows that Cronbach's (alpha) for this factor is 0.883 .The third factor accounts for 14.383 percent of total variance and is defined by its four items with factor loadings greater than 0.70 and was labeled "Subjective Norms". Table 1 above shows that Cronbach's (alpha) for this factor is 0.828 . The fourth factor accounts for 11.896 percent of total variance and is defined by its four items with factor loadings greater than 0.70 and was labeled "Perceived Behavioral Control". Table 1 above shows that Cronbach's (alpha) for this factor is 0.860 . The fifth factor accounts for 5.617 percent of total variance and is defined by one item with factor loadings greater than 0.70 and was labeled "intention to pursue accounting career in Lebanon”.

\section{Multiple Regression Analysis}

Tables 5-7 show the results of multiple linear regression. The regression analysis with the enter method elimination retained "Subjective Norms" in the model and removed "Beliefs and Attitude towards Accountant and 
Table 1. Reliability statistics.

\begin{tabular}{|c|c|}
\hline Cronbach’s Alpha & $\mathrm{N}$ of Items \\
\hline 0.828 & 4 \\
\hline \multicolumn{2}{|c|}{ Reliability Statistics } \\
\hline Cronbach’s Alpha & $\mathrm{N}$ of Items \\
\hline 0.860 & 4 \\
\hline \multicolumn{2}{|c|}{ Reliability Statistics } \\
\hline Cronbach’s Alpha & $\mathrm{N}$ of Items \\
\hline 0.883 & 4 \\
\hline \multicolumn{2}{|c|}{ Reliability Statistics } \\
\hline Cronbach’s Alpha & $\mathrm{N}$ of Items \\
\hline 0.907 & 5 \\
\hline \multicolumn{2}{|c|}{ Table 2. KMO and Bartlett's test. } \\
\hline Kaiser-Meyer-Olkin Measure of Sampling Adequacy. & 0.674 \\
\hline \multirow{3}{*}{ Bartlett's Test of Sphericity } & 4834.326 \\
\hline & 153 \\
\hline & 0.000 \\
\hline
\end{tabular}

Table 3. Total variance explained.

\begin{tabular}{|c|c|c|c|c|c|c|c|}
\hline \multirow{2}{*}{ Component } & \multicolumn{3}{|c|}{ Initial Eigenvalues } & \multicolumn{3}{|c|}{ Extraction Sums of Squared Loadings } & \multirow{2}{*}{$\begin{array}{c}\begin{array}{c}\text { Rotation Sums } \\
\text { of Squared } \\
\text { Loadings }^{\mathrm{a}}\end{array} \\
\text { Total }\end{array}$} \\
\hline & Total & $\%$ of Variance & Cumulative \% & Total & $\%$ of Variance & Cumulative \% & \\
\hline 1 & 5.380 & 29.891 & 29.891 & 5.380 & 29.891 & 29.891 & 4.349 \\
\hline 2 & 3.174 & 17.632 & 47.523 & 3.174 & 17.632 & 47.523 & 3.598 \\
\hline 3 & 2.589 & 14.383 & 61.906 & 2.589 & 14.383 & 61.906 & 3.016 \\
\hline 4 & 2.141 & 11.896 & 73.802 & 2.141 & 11.896 & 73.802 & 3.310 \\
\hline 5 & 1.011 & 5.617 & 79.419 & 1.011 & 5.617 & 79.419 & 1.441 \\
\hline 6 & 0.662 & 3.679 & 83.098 & & & & \\
\hline 7 & 0.562 & 3.123 & 86.220 & & & & \\
\hline 8 & 0.515 & 2.864 & 89.084 & & & & \\
\hline 9 & 0.398 & 2.214 & 91.298 & & & & \\
\hline 10 & 0.321 & 1.781 & 93.079 & & & & \\
\hline 11 & 0.250 & 1.388 & 94.466 & & & & \\
\hline 12 & 0.234 & 1.298 & 95.764 & & & & \\
\hline 13 & 0.199 & 1.105 & 96.869 & & & & \\
\hline 14 & 0.182 & 1.014 & 97.883 & & & & \\
\hline 15 & 0.140 & 0.777 & 98.659 & & & & \\
\hline 16 & 0.115 & 0.636 & 99.296 & & & & \\
\hline 17 & 0.077 & 0.429 & 99.725 & & & & \\
\hline 18 & 0.049 & 0.275 & 100.000 & & & & \\
\hline
\end{tabular}

Extraction Method: Principal Component Analysis. a. When components are correlated, sums of squared loadings cannot be added to obtain a total variance. 
Table 4. Structure matrix.

\begin{tabular}{|c|c|c|c|c|c|}
\hline & \multicolumn{5}{|c|}{ Component } \\
\hline & 1 & 2 & 3 & 4 & 5 \\
\hline Choice of accounting profession implies high job security & 0.895 & 0.226 & 0.098 & 0.249 & $-0.228-$ \\
\hline Choice of accounting profession implies advancement opportunities & 0.889 & 0.147 & 0.165 & 0.186 & 0.191 \\
\hline Choice of accounting profession implies good long term earnings & 0.885 & 0.181 & 0.169 & 0.154 & 0.080 \\
\hline Choice of accounting profession implies structured career path & 0.807 & 0.181 & 0.119 & 0.309 & 0.275 \\
\hline Choice of accounting profession implies exciting profession & 0.783 & $-0.051-$ & 0.059 & 0.408 & $-0.267-$ \\
\hline I am good at analyzing and solving business-related problems & 0.203 & 0.936 & 0.159 & 0.085 & $-0.058-$ \\
\hline $\begin{array}{l}\text { I am usually able to recognize and comprehend the meaning and } \\
\text { application of a particular }\end{array}$ & 0.344 & 0.833 & 0.090 & $-0.105-$ & -0.223 \\
\hline $\begin{array}{l}\text { I am usually able to locate and extract relevant information from } \\
\text { available resource materials }\end{array}$ & 0.017 & 0.824 & 0.170 & 0.059 & -0.006 \\
\hline $\begin{array}{l}\text { I am good at evaluating options for decision-making and reaching } \\
\text { conclusions }\end{array}$ & 0.162 & 0.802 & 0.151 & 0.145 & 0.148 \\
\hline My close friends would think I should major in Accounting & $-0.075-$ & 0.271 & 0.860 & 0.110 & 0.100 \\
\hline My significant-other would think that I should major in Accounting & 0.098 & $-0.036-$ & 0.834 & 0.056 & 0.231 \\
\hline My family would think that I should major in Accounting & 0.165 & $-0.097-$ & 0.776 & 0.009 & 0.490 \\
\hline My teacher would think that I should major in Accounting & 0.358 & 0.406 & 0.771 & 0.136 & $-0.168-$ \\
\hline I am confident that I can get promoted in accounting profession & 0.360 & 0.129 & 0.136 & 0.873 & $-0.061-$ \\
\hline I am confident that I can bocome a CPA & 0.058 & 0.417 & 0.042 & 0.823 & $-0.021-$ \\
\hline I am confident that I can bocome a professional accountant & 0.354 & $-0.169-$ & 0.026 & 0.817 & 0.391 \\
\hline $\begin{array}{l}\text { I am confident that I build the capacity and autonomy aspects needed } \\
\text { for CPA profession }\end{array}$ & 0.234 & $-0.212-$ & 0.146 & 0.813 & 0.244 \\
\hline $\begin{array}{l}\text { Assuming I satisfy the requirements to major in Accounting, I } \\
\text { intend/plan to major in Accounting }\end{array}$ & 0.201 & 0.229 & 0.418 & 0.288 & 0.759 \\
\hline
\end{tabular}

Extraction Method: Principal Component Analysis. Rotation Method: Oblimin with Kaiser Normalization.

Table 5. Model summary.

\begin{tabular}{ccccc}
\hline Model & R & R Square & Adjusted R Square & Std. Error of the Estimate \\
\hline 1 & $0.223^{\mathrm{a}}$ & 0.050 & 0.029 & 0.98816930 \\
\hline
\end{tabular}

a. Predictors: (Constant), Perceived Behavioral Control, Taking Risk, Self Efficacy, Are you currently employed?, Gender, Subjective Norms, Beliefs and Attitude towards Accountant and CPA.

Table 6. ANOVA

\begin{tabular}{|c|c|c|c|c|c|c|}
\hline & Model & Sum of Squares & df & Mean Square & $\mathrm{F}$ & Sig. \\
\hline \multirow{3}{*}{1} & Regression & 16.125 & 7 & 2.304 & 2.359 & $0.023^{\mathrm{b}}$ \\
\hline & Residual & 307.591 & 315 & 0.976 & & \\
\hline & Total & 323.715 & 322 & & & \\
\hline
\end{tabular}

a. Dependent Variable: intention to pursue accounting career in Lebanon; b. Predictors: (Constant), Perceived Behavioral Control, Taking Risk, Self Efficacy, Are you currently employed?, Gender, Subjective Norms, Beliefs and Attitude towards Accountant and CPA. 
Table 7. Coefficients ${ }^{\mathrm{a}}$.

\begin{tabular}{|c|c|c|c|c|c|c|}
\hline & \multirow{2}{*}{ Model } & \multicolumn{2}{|c|}{ Unstandardized Coefficients } & \multirow{2}{*}{$\begin{array}{c}\text { Standardized } \\
\text { Coefficients } \\
\text { Beta }\end{array}$} & \multirow[t]{2}{*}{$\mathrm{t}$} & \multirow{2}{*}{ Sig. } \\
\hline & & B & Std. Error & & & \\
\hline \multirow{8}{*}{1} & (Constant) & -0.037 & 0.112 & & -0.326 & 0.745 \\
\hline & Gender & -0.011 & 0.116 & -0.005 & -0.093 & 0.926 \\
\hline & Are you currently employed? & 0.022 & 0.122 & 0.010 & 0.185 & 0.853 \\
\hline & Taking Risk & 0.082 & 0.111 & 0.041 & 0.736 & 0.462 \\
\hline & $\begin{array}{l}\text { Beliefs and Attitude towards } \\
\text { Accountant and CPA }\end{array}$ & -0.019 & 0.057 & -0.019 & -0.324 & 0.746 \\
\hline & Self Efficacy & -0.090 & 0.056 & -0.089 & -1.598 & 0.111 \\
\hline & Subjective Norms & 0.186 & 0.056 & 0.186 & 3.331 & 0.001 \\
\hline & Perceived Behavioral Control & 0.093 & 0.057 & 0.093 & 1.637 & 0.103 \\
\hline
\end{tabular}

a. Dependent Variable: intention to pursue accounting career in Lebanon.

CPA", "Self Efficacy", and "Perceived Behavioral Control". This implies that rating the extent to which important others would affect intention to pursue the accounting profession is a significant factor in Lebanon. All the parameter estimates of the other variables were not significant. In other words, the parameters of all of the other variables are not significantly differently from 0 . The interpretations on the parameter estimates are straight forward. Out of the seven independent variables explicitly brought into the causal model, only (the perceptions of social pressure) is the variable affecting intention to pursue accounting career in Lebanon. The effect of "Subjective Norms" reflecting effects of (the perceptions of social pressure) is shown in the following regression model:

$\mathrm{Y}=\mathrm{a}+\mathrm{bX}$ where $\mathrm{X}$ is "Subjective Norms" and $\mathrm{Y}$ is "intention to pursue accounting career in Lebanon".

\section{Conclusion, Recommendations and Implications}

The present study examined a modified theory of planned behavior to predict intention to pursue accounting career in Lebanon. Findings of multiple regression analysis showed that only an explanatory variable out of the seven independent variables was significant. The current study showed that path analysis was not an acceptable fit of data. All predictors (paths) except the direct effect between "Subjective Norms" and "intention to pursue accounting career in Lebanon" should be deleted from the model. Findings of this study support that Hypothesis 1-Subjective Norms (perceived social pressure to become or not become CPA) will be a significant positive predictor of intention to pursue a CPA Career. On the one hand, the results of the multiple regression analysis in this study serve to support previous research that "'intrinsic factors' (attitude toward the behavior) and 'parental influence' (subjective norms), make significant and independent contributions to predicting the career choice of accounting students" [13] and agree with Maheran, Z., Wan, N.A.W.F. and Siti, J.N.H. [25] on the impact of referrals in choosing accounting profession. The analysis highlighted the importance of "Subjective Norms" in predicting intention to pursue accounting career in Lebanon. Future policy makers and researchers are challenged to design and plan research using different theoretical causal models such as AIDA model to explain Attention, Interest, Desire, and Action in accounting profession. Suggesting such new models should help in answering different research questions such as:

- How do we make business students more aware of the importance of the accounting profession?

- What make accounting profession more desirable?

- How to gain the interest of students in accounting profession?

- What are the actions and how to place them on social media?

It is imperative to note here that [27] in Harvard Business school "individuals perceive those who seek advice as more competent than those who do not seek advice". Moreover, Yaniv, I. [28] notes that "It is imperative for future research to consider the procedures by which various type of advice (e.g., qualitative verbal advice, opinions about matters of taste) are elicited and used best". 


\section{References}

[1] Albrecht, W.S. and Sack, R.J. (2000) Accounting Education: Changing the Course through a Perilous Future. Accounting Education Series, No.16, American Accounting Association, Saratosa.

[2] Jackling, B. (2002) Are Negative Perceptions of the Accounting Profession Perpetuated by the Introductory Accounting Course? An Australian Study. Asian Review of Accounting, 10, 62-80. http://dx.doi.org/10.1108/eb060758

[3] Marshall, R. (2003) Calling on Tomorrow’s Professionals. Chartered Accountants Journal, 82, 4-9.

[4] Wells, P. and Fieger, P. (2005) High School Teachers' Perceptions of Accounting: An International Study. AFAANZ Conference, Melbourne, 3-5 July 2005.

[5] Sugahara, S., Hiramatsu, K. and Boland, G. (2009) The Accounting Profession as a Career Choice for Tertiary Business Students in Japan-A Factor Analysis. Accounting Education, 18, 255-272. http://dx.doi.org/10.1080/09639280701820035

[6] Solikhah, B. (2014) An Application of Theory of Planned Behavior towards CPA Career in Indonesia. International Conference on Accounting Studies (ICAS), Putra World Trade Centre, Kuala Lumpur, 18-19 August 2014, 397-402. http://dx.doi.org/10.1016/j.sbspro.2014.11.094

[7] Hejazi, R. and Bazrafshan, A. (2013) The Survey of Graduated Accounting Students. Interest in Management Accounting: Evidence of Iran. Open Journal of Accounting, 2, 87-93. http://dx.doi.org/10.4236/ojacct.2013.23011

[8] Hutaibat, K.A. (2012) Interest in the Management Accounting Profession: Accounting Students' Perceptions in Jordanian Universities. Asian Social Science, 8, 303-316. http://dx.doi.org/10.5539/ass.v8n3p303

[9] Joshi, P.L., Bremser, W.G. and Al-Ajmi, J. (2008) Perceptions of Accounting Professionals in the Adoption and Implementation of a Single Set of Global Accounting Standards: Evidence from Bahrain. Advances in Accounting, 24, 41-48. http://dx.doi.org/10.1016/j.adiac.2008.05.007

[10] Saleh, H.A. (2014) The Perceptions of the Lebanese Students of Choosing Their Career in Entrepreneurship. Jordan Journal of Business Administration, 10, 333-363.

[11] Ajzen, I. (1991) The Theory of Planned Behavior. Organizational Behavior and Human Decision Process, 50, $179-211$. http://dx.doi.org/10.1016/0749-5978(91)90020-T

[12] Buchan, H. (2005) Ethical Decision Making in the Public Accounting Profession: An Extension of Ajzen's Theory of Planned Behavior. Journal of Business, 61, 165-181. http://dx.doi.org/10.1007/s10551-005-0277-2

[13] Law, P.K. (2010) A Theory of Reasoned Action Model of Accounting Students' Career Choice in Public Accounting Practices in the Post-Enron. Journal of Applied Accounting Research, 11, 58-73. http://dx.doi.org/10.1108/09675421011050036

[14] Mbawuni, J. and Nimako, S.G. (2015) Modelling Job-Related and Personality Predictors of Intention to Pursue Accounting Careers among Undergraduate Students in Ghana. World Journal of Education, 5, 65-81.

[15] Djatej, A., Chen, Y., Eriksen, S. and Zhou, D. (2015) Understanding Students’ Major Choice in Accounting: An Application of the Theory of Reasoned Action. Global Perspectives on Accounting Education, 12, 53-72.

[16] Nahariah, J., Norhazlin, I. and Salmi, M.Z. (2015) Determinants of the Accounting Students' Preference to Practice as Chartered Accountant in Malaysia. Accountancy Business and the Public Interest, 14, 43-59.

[17] Danziger, N. and Eden, Y. (2007) Gender-Related Differences in the Occupational Aspirations and Career Style Preferences of Accounting Students. Career Development International, 12, 129-149. http://dx.doi.org/10.1108/09675421011050036

[18] ACCA (2016) Our History. http://www.accaglobal.com/middle-east/en/discover/about/history.html

[19] The Economist (1997) The Big Five. http://www.economist.com/node/157334

[20] Accountingverse (2016) Big 4 Accounting Firms. Accountingverse. http://www.accountingverse.com/articles/big-4-accounting-firms.html

[21] Longuenesse, E. (2009) Globalization and the Accounting Profession in Emergent Economies—Restructuring the Profession and Increasing Role of the "Big Five" International Audit Firms: The Case of Egypt and Lebanon. SASE Conference, Paris, 16-18 July 2009, 1-12. https://halshs.archives-ouvertes.fr/halshs-00917220/document

[22] Mbekomize, C.J. and Kiiru, J.O.W. (2013) Assessment of Students' Attitudes towards the Accounting Profession: The Case of University of Botswana. Botswana Journal of Business, 6, 60-73.

[23] Lillian, B. and Wally, D. (2013) Factors Influencing Students Choice of Accountants as a Major: The Case of Botswana Accounting Students. Asian Journal of Empirical Research, 3, 464-476.

[24] Yaacoub, N. and Badre, L. (2012) Education in Lebanon. The Central Administration of Statistics in Lebanon.

[25] Maheran, Z., Wan, N.A.W.F. and Siti, J.N.H. (2012) Accounting as a Choice of Academic Program. Journal of Busi- 
ness Administration Research, 1, 43-52.

[26] Foerster, M., Deputy Chair (2015) IFAC SMP Committee and Rogério Garcia, Technical Director, IBRACON. https://www.ifac.org/global-knowledge-gateway/audit-assurance/discussion/creating-optimized-environment-audit-qua lity

[27] Brooks, A.W., Gino, F. and Schweitzer, M.E. (2015) Smart People Ask for My Advice: Seeking Advice Boosts Perceptions of Competence. Management Science, 61, 1421-1435. http://dx.doi.org/10.1287/mnsc.2014.2054

[28] Yaniv, I. (2004) Receiving Other Peoples Advice: Influence and Benefit. Organizational Behavior and Human Decision Processes, 93, 1-13. http://dx.doi.org/10.1016/j.obhdp.2003.08.002 